\title{
NOTES
}

\section{OLD ENGLISH 'WUNDENLOCC' HAIR IN CONTEXT'}

The compound 'wundenlocc' (locks that have been wound) is applied to 'hair' four times across two Old English poems: once in Riddle $25^{2}$ (onion) and three times in Judith. In all of these instances, its meaning has been subject to debate because it is not clear whether wunden indicates hair that has been braided or hair that is curly. Several scholars prefer the sense 'braided', including Joseph Bosworth and T. Northcote Toller, ${ }^{3}$ J. R. Clark Hall, ${ }^{4}$ Elinor Teele, ${ }^{5}$ and Patrick Murphy. ${ }^{6}$ Others prefer the sense 'curly-haired', including Craig Williamson, ${ }^{7}$ S. A. J. Bradley, ${ }^{8}$ John P. Hermann, ${ }^{9}$ and Susan Kim. ${ }^{10}$ Some, as is the case with Mark S. Griffith ${ }^{11}$ and F. Tupper, ${ }^{12}$ offer both options. ${ }^{13}$ Given the context of these instances as well as that of similar compounds and collocations, which I shall outline below, in my view the 'curly hair' reading appears to be the sounder of the two.

The first occurrence, from the famously double-entendre onion riddle, reads:

\section{Felep sona}

mines gemotes, seo ${ }^{14}$ pe mec nearwað, wif wundenlocc. (lines 9 a-ı гa)

(Immediately she feels my might, she who confines me, the wundenlocc woman.)

This poem refers to the beautiful daughter of a 'ceorl' (line 6b) (freeman) who either places an onion in her food-bag, according to the accepted solution, or forces herself upon an unwilling penis, according to the double-entendre solution. The descriptor, 'wundenlocc', is not directly relevant to the riddlesubject, ${ }^{15}$ although, alliterating with both line I I's 'wif' (woman) and 'wæt' (wet), it does help point to both the domestic and double-entendre contexts of the onion/penis.

Past scholarship on this riddle has generally pointed to Judith for clarification of the term in question. Hence, the commentary in Tupper's edition argues that '[c]urled or braided locks were regarded by the Anglo-Saxons as an accessory of beauty', linking it to the 'twisted hairs of the fair Judith'. ${ }^{16}$ However, more recently, scholars have begun to look at other contexts. Teele points out that in the riddles, '[c]ompounds with locc are always sexual', directing readers not only to this text, but also to Riddle 42 (cock and hen), where the frisky hen is 'hwitloc' (line 3 b) (fair-haired). ${ }^{17}$ It is perhaps unfair to argue that just because -locc appears in two double-entendre riddles, it must in itself denote sexuality. The riddles in general are naturally given to describing appearances, containing in particular more body-terms than any other Old English poetry. ${ }^{18}$ Thus, visible 
or free-flowing locks are perhaps more appropriately to be 'considered [as] an accessory of great beauty'. ${ }^{19}$

Following this, the somewhat higher-brow Judith refers to the heroine using the term in two particularly martial passages:

Genam ða wundenlocc

scyppendes mægð scearpne mece, scurum heardne, ond of sceaðe abræd swiðran folme. (lines $77 \mathrm{~b}-8 \mathrm{oa}$ )

(Then the wundenlocc one, the creator's maiden, took a sharp sword, hard from storms of battle, and drew it from the sheath with her right hand.)

and

Sloh ða wundenlocc

pone feondsceaðan fagum mece, heteponcolne. (lines io3b-io5a)

(Then the wundenlocc one struck the fiendish foe, the hateful one, with a gleaming sword.)

The third reference, this time to the Hebrew nation, similarly involves references to swords and armour: [the people],

wlanc, wundenlocc, (w)ægon ond læddon

to ðære beorhtan byrig, Bethuliam,

helmas ond hupseax, hare byrnan,

guðsceorp gumena golde gefrætewod,

mare madma ponne mon ænig

asecgan mæge searoponcelra. (lines 325-30)

(proud, wundenloce, carried and led to that bright city, Bethulia, helmets and shortswords, grey corselets, the battle equipment of men adorned with gold, more treasure than anyone, however cunning, could recount.)

The alliterative context of each of these instances is different: 'wundenlocc' alliterates with 'womfull' (sinful) and 'onwoce' (awoke) in line 77, with 'wel' (well) and 'gewealdan' (control) in line ro3, and with 'wlanc' (proud) and 'wægon' (carried) in line 325. Despite the fact that it appears all three times in collocations with weapons (implying a formulaic context), what we have here seems to point to a thematic association with violence and sin, as well as high-spiritedness or pride, the woman of Riddle 25 also being 'modwlonc' (line 7a), just as the hen of Riddle 42 is 'wlanc' (line $4 \mathrm{a}$ ).

Riddle 25's sexual connotations and Judith's own treatment of attempted sexual violence cause both Hermann and Kim to read the decapitation of Holofernes in a rather grim light. Looking at the two texts together, Kim argues that the reference to the onion's shagginess 'underneath' indicates pubic hair, a reading which she claims is wholly appropriate given the sexually charged nature of Judith's decapitation scene. ${ }^{20}$ In Hermann's own analysis, he argues that the riddle content refers to both castration by and intercourse with the 'wundenlocc' woman. ${ }^{21}$ Thus, for him, the riddle expresses both a castration complex and 
sexual stimulation at the thought of such an aggressive woman, an idea that is carried through to Judith, which similarly 'elicits ambivalent emotional responses to the wundenlocc heroine, who is both object of desire and violent avenger of those who desire unmediated access to her'. ${ }^{22}$

Although evidence for a sexual reading of the term wundenlocc is strong due to the nature of the passages in which it is used, we must also keep in mind that the term is applied to a whole nation of people who are painted as morally superior. Thus, while similar context may seem to colour the use of the term in Riddle 25 and Judith, wundenlocc appears to be primarily a physical marker. Both braided and curly hair may act as such a marker, although the latter is perhaps more appropriate than the former in distinguishing a cultural group, ${ }^{23}$ especially when we consider that bound and braided hair were also common among Anglo-Saxon women. ${ }^{24}$ Either way, as Hugh Magennis notes, 'wundenlocc seems to belong with beagum gehlaste, hringum gehrodene and golde gefratwod as part of the vocabulary of adornment rather than as referring to natural beauty'. ${ }^{25}$ Thus Bradley translates the references to Judith herself as 'ringletted', ${ }^{26}$ implying that some care has been given to her hair's appearance.

If we look to the apocryphal Book of Judith for a solution, we find that 'wundenlocc' has been wholly supplied by the poet in each scene of the Old English poem. ${ }^{27}$ However, in an earlier scene, the Latin Vulgate does describe the heroine's adornment in terms of her fixing her hair: 'et discriminavit crinem capitis sui' (and she separated the hair of her head). ${ }^{28}$ This Latin text is not particularly helpful in discerning whether Judith has braided or curled her hair because of the ambiguity of 'discriminare', which can mean 'to divide, part, separate', 'to distinguish', or 'to apportion', ${ }^{29}$ all of which could easily refer to both the braiding and curling of hair.

In addition to these instances of the term wundenlocc, there is also a similar compound, 'wundenfeax' (wound-hair), which the Beowulf-poet uses to refer to a horse's mane (line I400a). This, the most recent editors gloss as both 'with (WOUND) braided hair' and 'with curly mane' ${ }^{30}$ Magennis, however, argues that "the meaning must be "with braided mane" although he does not give a reason as to why this must be so. ${ }^{31}$ Here, Clark Hall skirts around the issue of braided versus curly hair, defining 'wundenfeax' as 'with twisted mane' ${ }^{32}$ In addition to being neutral, this definition is also perhaps the most appropriate given the texture of horsehair, which is not particularly prone to curling (I assume this is the thinking behind Magennis's statement, as well).

A final compound which may or may not be relevant also appears in Beowulf, this time referring to the female mourner at the hero's funeral:

$$
\begin{aligned}
& \text { swylce giomorgyd (Ge)at(isc) meowle } \\
& \text { (æfter Biowulfe b) undenheorde } \\
& \text { (sang) sorgcearig. (lines 3 I 50-2a) }
\end{aligned}
$$

(likewise a woman of the Geats with bound hair sang a mournful song about Beowulf.)

Due to the damaged state of the manuscript, the first letter in what has traditionally 
been interpreted as 'bundenheorde' is indistinct. Thus, Carol J. Clover argues that it should read 'wundenheorde', ${ }^{33}$ wunden being a common enough (certainly more common than bunden) descriptor for hair in Old English poetry, as the examples already discussed demonstrate. Clover further argues that, although bound hair may have been the usual custom for women in the Anglo-Saxon period, ' $[t]$ hroughout the world, people in mourning tend to reverse their normal habits of dress and appearance. ${ }^{34}$ She outlines the prevalence of the unbinding of hair during mourning across European sources ${ }^{35}$ thus making the descriptor, 'bundenheorde', 'quite inappropriate to mourning women, married or otherwise, who are widely described, even emblematized, as having unbound or dishevelled hair. The reading "[w] undenheorde", "wound- [=wavy-] haired" accords better with this picture. ${ }^{36}$ If this passage does read 'bundenheorde', which is a possibility, given the wideranging use of binding terminology in Beowulf and throughout the poetic record, then it is the only poetic instance of bunden being connected to hair. ${ }^{37}$

The final poem to refer to wound-locks, Riddle 40 (creation), does so through collocations rather than compounds, and it is perhaps because of this that it has been overlooked in scholarship. ${ }^{38}$ However, given that it links 'wunden' and 'locc' in lines 98b-99a and again in line I04, the information that it provides is invaluable for our understanding of this term. The relevant lines read:
$\mathrm{Ne}^{39}$ hafu ic in heafde hwite loccas
wræste gewundne, ac ic eom wide calu;
ne ic breaga ne bruna brucan moste,
ac mec bescyrede scyppend eallum;
nu me wrætlice weaxað on heafde
pæt me on gescyldrum scinan motan
ful wrætlice wundne loccas. (lines 98-104)

(I do not have white locks on my head, delicately wound, but I am bare far and wide; nor might I enjoy eyebrows nor eyelashes, but the creator sheared me entirely; now miraculously wound locks grow on my head, very beautifully, so that they might shine on my shoulders.)

Here we have locks of hair again described by the ambiguous term 'wunden'. Given that creation is personified (i.e. we cannot dismiss any aspect of its appearance based on whether or not a descriptor is particularly realistic due to its figurative and metaphorical nature), any type of hair, whether bound and braided or curly, might apply. However, because this poem is an adaptation of Aldhelm's Anglo-Latin Enigma I00, we have a valuable opportunity to clear up problems of interpretation. Unlike Judith, here we have a Latin text both written by an Anglo-Saxon and with directly corresponding lines:

Cincinnos capitis nam gesto cacumine nullos,

Ornent qui frontem pompis et tempora setis.

Cum mihi ceasaries uolitent de uertice crispae,

Plus calamistratis se comunt quae calamistro. (lines $44-7)^{40}$

(Upon my head I wear no curly locks / That deck the brow with hirsute finery, / Although about my face floats waving hair / More crisp than ringlets made with curling-irons. ${ }^{41}$ ) 
Several of the above terms point directly to curled hair: 'cincinnus', 'curled hair, a lock or curl of hair', 'crispus, -a, -um', 'curled, crisped, crimped', 'calamistratus, -a, -um', 'curled with a curling iron, crisped, curled', and 'calamister', 'curling iron'. ${ }^{42}$ The complete lack of ambiguity in this Latin poem offers definitive evidence that Old English 'loccas' that are 'wunden' can refer to curly or curled hair. Thus, in Riddle 40 at least, the Latin text allows us to safely rule out braided hair.

Furthermore, this collocation is more directly relevant to the interpretation of 'wundenlocc' than 'wundenfeax' or 'bunden/wundenheorde' because both elements of the compound are present (twice!). Therefore, readings that take the other compounds into account but neglect the collocation offer only half the picture; if we really want to know what 'wundenlocc' means, we have to consider all of the evidence. This evidence demonstrates, as I hope the above discussion has shown, that the term can definitely refer to curly hair. Whether or not it denotes braided hair as well remains speculative.

University of Toronto

MEGAN CAVELL

\section{NOTES}

1 The conclusion put forth in this paper appears in a brief footnote in my paper 'Looming danger and dangerous looms: violence and weaving in Exeter Book Riddle s 6 , Leeds Studies in English, 42 (201 I), 29-42 (p. 34 n. 28).

${ }^{2}$ Riddle numbering and quotations follow those of The Exeter Book, ed. Elliott van Kirk Dobbie and George Philip Krapp, Anglo-Saxon Poetic Record 3 (New York, 1936). Unless otherwise stated, all translations are my own.

${ }^{3}$ Joseph Bosworth, An Anglo-Saxon Dictionary (Oxford, I 898) and T. Northcote Toller, Supplement (Oxford, I 92 I), Digital Edition (Prague, 2010) <http://bosworth.ff.cuni.cz/> (accessed 8 November 201 I), s.v. 'wunden-locc'.

4 J. R. Clark Hall, A Concise Anglo-Saxon Dictionary, 4th edn (Toronto, i 960), s.v. 'wunden-locc'.

5 Elinor Teele, 'The heroic tradition in the Old English Riddles' (unpub. Ph.D. diss., University of Cambridge, 2004), p. 132.

${ }^{6}$ Patrick J. Murphy, Unriddling the Exeter Riddles (University Park, Pa, 20 I I), Pp. 203, 222, and $230-3$.

7 The Old English Riddles of The Exeter Book, ed. Craig Williamson (Chapel Hill, NC, i 977), p. 464.

8 Anglo-Saxon Poetry, ed. and trans. S. A. J. Bradley (London, i 982), pp. 373, 498, 499, and 503 .

9 John P. Hermann, Allegories of War: Language and Violence in Old English Poetry (Ann Arbor, Mich., i989), pp. igif.

${ }^{10}$ Susan Kim, 'Bloody signs: circumcision and pregnancy in the Old English Judith', Exemplaria, I I / 2 (Fall i 999), $285-307$.

11 Judith, ed. Mark Griffith, Exeter Medieval English Texts and Studies (Exeter, 1997), p. 222.

12 The Riddles of the Exeter Book, ed. F. Tupper (Boston, Mass., i 910), p. I 25.

13 Marie Nelson similarly offers both, though with no consistency. She translates the first instance of Judith as ' $[\mathrm{t}$ ] he woman with braided hair', the second simply as '[ $\mathrm{t}$ ] he brave woman', and the description of the Hebrews as 'with curly-locked heads'. See Judith, Juliana, and Elene: Three Fighting Saints, American University Studies: Series IV, English Language and Literature 135 (New York, I991), pp. Is and 29. 
${ }^{14}$ The manuscript reads 'se', but given the context most recent editors emend to 'seo'. See Old English Riddles, ed. Williamson, p. 82; Exeter Book, ed. Krapp and Dobbie, p. I93; and The Exeter Anthology of Old English Poetry, ed. Bernard J. Muir, 2 vols (Exeter, I 994), I, 306. However, Murphy argues that the emendation is not necessary if we read this as a general statement referring to the effect of the onion upon 'anyone' who confines it. See Unriddling, p. $232 \mathrm{f}$.

${ }^{15}$ Noteworthy here is Murphy's recent suggestion that 'wif wundenlocc' refers not only to the woman in the riddle, but also to the onion itself. He points to both the grammatical ambiguity of the neuter noun phrase, which can be read as both nominative and accusative, and to the later oral riddles collected by Archer Taylor in his English Riddles from Oral Tradition (Berkeley, Calif., I 95 I), p. I 96. Several of these riddles depict root vegetables as 'women with braided hair', indicating to Murphy that the descriptor could refer both back to the woman described in the riddle and forward to the personified onion. See Unriddling, pp. 230-3. Although I find this evidence both useful and intriguing, I would hesitate to use the later riddling examples as definitive proof for the 'braided' reading of 'wundenlocc'. Indeed, we do not and cannot know whether the oral riddles' descriptions derived from a form of the Old English term wundenlocc; their use of 'braided' could easily stem from their Old English root, bregdan, which can mean 'to weave, intertwine'. See $D O E$, s.v. 'bregdan', 2-2.c. Furthermore, even if they did stem from riddling uses of 'wundenlocc', the definition of the term could well have changed over the years, as is the case with many modern English reflexes. Thus, I think it is wiser to restrict this discussion to the Anglo-Saxon textual evidence at hand.

${ }_{16}$ Riddles, ed. Tupper, p. I 25.

17 Teele, 'Heroic tradition', p. I32.

18 John W. Tanke, 'Wonfeax wale: ideology and figuration in the sexual riddles of the Exeter Book', in Class and Gender in Early English Literature: Intersections, ed. Britton J. Harwood and Gillian R. Overing (Bloomington, Ind., I 994), pp. 2 I-42 (p. 27).

19 Edith Whitehurst Williams, 'What's so new about the sexual revolution? Some comments on Anglo-Saxon attitudes toward sexuality in women based on four Exeter Book riddles', Texas Quarterly, i 8/2 (1975), 46-55 (repr. in New Readings on Women in Old English Literature, ed. Helen Damico and Alexandra Hennessey Olsen (Bloomington, Ind., I 990), pp. 137-45 (p. 140)).

${ }^{20}$ Kim, 'Bloody signs', p. 299.

${ }^{21}$ Hermann, Allegories of War, p. 192.

22 Ibid.

23 Hermann also notes this. See Allegories of War, p. i91.

${ }^{24}$ Gathering evidence from a variety of textual and material sources, Gale R. OwenCrocker concludes that head-coverings were usual for both Anglo-Saxon women and girls after the conversion. See Dress in Anglo-Saxon England (Manchester, I 986), p. I 57. Under the headdress it was common to find a fillet referred to as a binde or bindan, which would hold the hair in place. See Owen-Crocker, 'Women's costume in the tenth and eleventh centuries and textile production in Anglo-Saxon England', in The Archaeology of Anglo-Saxon England: Basic Readings, ed. Catherine E. Karkov (New York, I 999), pp. 423-85 (p. 435). In most Anglo-Saxon art women's hair tends to be hidden, but Owen-Crocker points to one instance of an image of the Virgin Mary on a book-cover, which 'shows what appears to be a plait of hair over the crown, suggesting that women in the late Anglo-Saxon period were wearing their hair up'. See 'Women's costume', p. 437.

${ }^{25}$ Hugh Magennis, 'Gender and heroism in the Old English Judith', in Writing Gender and Genre in Medieval Literature: Approaches to Old and Middle English Texts, ed. Elaine Treharne (Cambridge, 2002), Pp. 5-I 8 (p. I4). 
26 Anglo-Saxon Poetry, ed. and trans. Bradley, pp. 498 and 499.

27 Likewise it does not appear (nor do any references to Judith's or the Hebrews' hair) in Ælfric's prose homily. See Ælfric, 'Judith', ed. Stuart D. Lee, in Elfric's Homilies on Judith, Esther and the Maccabees, I 999 <http://users.ox.ac.uk/ stuart/kings/> (accessed 8 November 20I I).

${ }^{28}$ Bible: Judith X.3.

29 'T. Charlton Lewis and Charles Short, A Latin Dictionary. Founded on Andrews' Edition of Freund's Latin Dictionary: Revised, Enlarged, and in Great Part Rewritten, I 879 (Oxford, I945), s.v. 'discriminare'.

${ }^{30}$ Klaeber's Beowulf, ed. R. D. Fulk, Robert E. Bjork, and John D. Niles, 4th edn (Toronto, 2008), p. $46 \mathrm{I}$.

31 Magennis, 'Gender and heroism', p. I4.

32 Clark Hall, Concise Anglo-Saxon Dictionary, s.v. 'wunden-feax'.

33 Carol J. Clover, 'Hildigunnr's lament', in Structure and Meaning in Old Norse Literature, ed. John Lindow, Lars Lönnroth, and Gerd Wolfgang Weber (Odense, I 986), pp. 141-83 (p. I67).

34 Ibid, p. I62.

35 Ibid, p. I63.

${ }^{36}$ Ibid, p. I67. The square brackets around 'wavy' are Clover's own.

37 The presence of this term has been used as evidence for the age and married status of the female mourner by those who would argue that the woman is Beowulf's widow or Hygd. See Klaeber's Beowulf, ed. Fulk et al., p. 270 . However, it does not necessarily follow that the woman must be somehow related to Beowulf in order to mourn his death, the role being a standard female one. See Clover, 'Hildigunnr's lament', p. i62. Furthermore, while there is some evidence to suggest that bound hair indicates a married woman, much of this material is Roman or early Germanic. See Penelope Walton Rogers, Cloth and Clothing in Early Anglo-Saxon England: AD 450-700 (York, 2006), p. 243. As noted above (n. 24), it is difficult to firmly identify the nature of post-conversion hairstyles due to the use of head-coverings for women of all ages. The Anglo-Saxon image of the plaitedhaired Virgin Mary does not help shed light on this issue because she is both a virgin and a married woman, implying that either young/virginal women or married women or both may have bound their hair in Anglo-Saxon England. Given all of these factors, it is virtually impossible to distinguish who the female mourner in Beowulf is.

${ }^{38}$ See Elizabeth M. Tyler, Old English Poetics: The Aesthetics of the Familiar in Anglo-Saxon England (York, 2006) for more on the importance of a wide variety of formulaic techniques in Old English poetics. In particular, she argues that scholarship has profoundly misunderstood the Old English formula, the definition of which should include the collocation, which itself 'places formulas in a wider linguistic context', taking into account not only function, but also style (p. гог).

${ }^{39}$ I have accepted Williamson's reading of the text here rather than that of Krapp and Dobbie. He argues that they misread the manuscript, printing 'Nu' when it actually reads 'Ne'. See Old English Riddles, p. 274. Given the context, as well as the Latin version of the riddle, ' $\mathrm{Ne}$ ' does seem to make more sense.

40 Variae collectiones aenigmatum Merovingicae aetatis, ed. and trans. F. Glorie, Corpus Christianorum Series Latina CXXXIII-CXXXIII A (Turnhout, I 968), CXXXIII, 535.

${ }^{41}$ Ibid., CXXXIII, 534.

${ }^{42}$ Lewis and Shortt, Latin Dictionary, s.v. 'cincinnus', 'crispus', calamistratus', and 'calamister'. 